\title{
PREVALENCE OF HEPATITIS C
} VIRUS IN ALCOHOLIC PATIENTS: role of parenteral risk factors

\author{
Bruno GALPERIM ${ }^{1}$, Hugo CHEINQUER ${ }^{2}$, Airton STEIN ${ }^{2}$, \\ André FONSECA ${ }^{3}$, Vagner LUNGE $^{3}$ and Nilo IKUTA ${ }^{3}$
}

ABSTRACT - Background - The prevalence of hepatitis C virus (HCV) infection is elevated in alcoholic patients, but the risk factors are unclear. The role of parenteral risk factors are indeterminated in this population. Aims - To determine the prevalence of hepatitis $\mathrm{C}$ virus infection in alcoholic patients admitted to a detoxification unit and to evaluate the presence of underlying parenteral risk factors. Methods - A total of 114 consecutive unselected alcoholic patients admitted to a single chemical dependency unit during 14 month were included. Epidemiological data and history of parenteral risk factors for hepatitis $\mathrm{C}$ virus infection were obtained with a standardized questionnaire. Blood was collected for determination of aminotransferases and anti-hepatitis C virus antibodies (ELISA-3). Positive samples were confirmed by polymerase chain reaction and tested for genotype. Results - Among the 114 alcoholics, 17 (15\%) were anti-hepatitis C virus positive. Of these, 12 (71\%) had detectable serum HCV-RNA by PCR. Genotype 1 was found in six cases and genotype 3 in five (one patient was undetermined). Forty-nine (43\%) patients had elevated serum ALT and/or AST at baseline. The comparison between the 17 positive and the 97 negative patients showed significant differences in mean serum ALT levels (42 $\pm 41 \mathrm{IU} / \mathrm{L}$ vs. $22 \pm 20 \mathrm{IU} / \mathrm{L})$, rate of elevated ALT (65\% vs. 34\%), and presence of parenteral risk factors ( $94 \%$ vs. 10\%). Comparison between alcoholic patients with and without elevated aminotransferases showed significant difference only in the rate of positive anti-hepatitis $\mathrm{C}$ virus antibodies (24\% vs. $7 \%$ ). Furthermore, among the 17 anti-hepatitis $\mathrm{C}$ virus positive patients, the rate of detectable HCV-RNA was significantly higher in the 12 with elevated aminotransferases versus the 5 with normal aminotransferases ( $92 \%$ vs. $20 \%$ ). Conclusions - There was a high prevalence of anti-hepatitis C virus antibodies in alcoholics and the majority was confirmed by the presence of detectable HCV-RNA. Intravenous drug use was the main risk factor for hepatitis $\mathrm{C}$ virus infection in this population.

HEADINGS - Hepatitis C. Alcoholism. Substance abuse, intravenous.

\section{INTRODUCTION}

Hepatitis C virus (HCV) infects approximately 200 million people worldwide and is presently considered one of the main causes of chronic liver disease in most parts of the world ${ }^{(18)}$. HCV is known to be transmitted primarily by the parenteral route, mainly through exposure to contaminated blood and/or blood products ${ }^{(9)}$. The main risk factor for HCV infection is currently intravenous drug use (IVDU), which accounts for $60 \%$ of $\operatorname{cases}^{(9)}$.

Several studies have demonstrated a high prevalence of anti-HCV among alcohol-dependent individuals but the mode of transmission is not clearly understood ${ }^{(4,7,10,}$ $13,20,21,22,23,24,26,27,30,33)$.

The purpose of this study was to determine the prevalence of HCV infection in alcoholic patients admitted to a detoxification unit, and to evaluate the role of underlying parenteral risk factors.

\footnotetext{
The present study was performed at the Chemical Dependency Unit, "Hospital Mãe de Deus", Porto Alegre, RS, Brazil.

1 "Hospital Mãe de Deus"; ${ }^{2}$ Federal Faculty of Medical Sciences Foundation; ${ }^{3}$ Symbios Biotechnology and Lutheran University of Brazil, Porto Alegre, RS, Brazil.

Address for correspondence: Dr. Bruno Galperim - Rua Costa, 30/404 - 90110270 - Porto Alegre, RS, Brazil. E - mail: galperim@portoweb.com.br
} 


\section{PATIENTS AND METHODS}

\section{Patient selection and study design}

All patients were recruited from a single chemical dependency unit located at "Hospital Mãe de Deus", a tertiary general hospital in the city of Porto Alegre, RS, southern Brazil. A total of 114 alcoholic patients were consecutively admitted to this unit for treatment of alcoholic dependency during 14 month. All patients were prospectively interviewed by the same investigator, who was blinded to the $\mathrm{HCV}$ test results and used a standardized questionnaire designed to obtain epidemiological data, such as mean alcohol intake, history of intravenous drug use anytime, blood transfusion prior to 1992, and/or transfusion of blood products before 1987.

Informed consent was obtained from each patient, and approval for the study protocol was granted by the Ethics Committee of the institution. Inclusion criteria were defined as a diagnosis of alcohol dependency according to ICD-10 $0^{(34)}$, signed informed consent and availability of a blood sample for biochemical and serological tests. The only exclusion criterion was inability to answer the questionnaire. No patient was excluded from the study.

\section{Biochemical and serological investigations}

Blood was collected within the first 24 hours of admission for determination of serum levels of alanine aminotransferase (ALT; standard method), aspartate aminotransferase (AST; standard method) and antibodies to anti-HCV (COBAS CORE Anti-HCV EIA II; Roche Diagnostics). Patients with detectable anti-HCV antibodies underwent a second blood collection during admission to assess the presence of HCV RNA by polymerase chain reaction (PCR; COBAS AMPLICOR; Roche Diagnostics). Determination of HCV genotype was performed on PCR-positive samples using restriction fragment length polymorphism as previously described ${ }^{(29)}$.

\section{Data processing and statistical methods}

Descriptive methods were used in the univariate analysis. A bivariate analysis was also performed and yielded odds ratio (OR) and a 95\% confidence interval (CI). Stratified analyzes were used to assess the independent contribution of each exposure factor studied. In this analysis, the chi-square and the MantelHaenszel tests were used. The chi-square test was used for categorical variables (Fisher's exact test was used for values below 5). In regard to continuous variables, the analysis of variance (ANOVA) was used for data presenting normal distribution, and the Kruskal-Wallis test was used for nonparametric data ${ }^{2,}$ 12). Statistical significance was set at $P<0.05$.

\section{RESULTS}

\section{Patient characteristics}

A total of 114 alcoholic patients met inclusion criteria and were enrolled in the study. Of these, 97 (85\%) were male. Mean age was $41 \pm 13$ years (range: 15 to 72 ). All patients were white. Mean daily alcohol consumption was $206 \pm 171 \mathrm{~g}$ (range: 105 to 900 ) for a mean duration of $9 \pm 10$ years (range: 1 to 45 ). Regarding the presence of parenteral risk factors for $\mathrm{HCV}$ infection, $26(23 \%)$ of the 114 patients had either a history of intravenous drug use (13 cases), blood transfusion prior to 1992 (11 cases), or both factors associated ( 2 cases).

\section{Laboratory characteristics}

Among 114 alcoholics studied, a total of $17(15 \%)$ were found to be anti-HCV positive. Of these, 12 (71\%) also had detectable serum HCV-RNA by PCR. Genotype 1 was found in six cases and genotype 3 in five cases. One patient had an undetermined genotype. Forty-nine (43\%) of 114 patients had elevated serum ALT and/or AST at baseline.

\section{Comparison between alcoholic patients with and without anti-HCV antibodies}

When anti-HCV positive patients $(\mathrm{n}=17)$ were compared to anti-HCV negative patients $(\mathrm{n}=97)$, significant differences were observed in mean serum ALT values $(42 \pm 41 \mathrm{IU} / \mathrm{L}$ vs. $22 \pm 20$ IU/L, respectively; $P=0.02$ ), number of patients with elevated ALT ( $65 \%$ vs. $34 \%$, respectively; $P=0.02)$, and presence of parenteral risk factors ( $94 \%$ vs. $10 \%$ respectively; $P<0.001),(\mathrm{OR}=$ 139,2, 95\% CI: 16-3129). There was no significant difference between both groups regarding the following variables: sex, mean age, mean daily alcohol consumption, mean duration of alcohol and AST/ALT ratio (Table 1).

TABLE 1 - Comparison between 114 alcoholics with and without anti$\mathrm{HCV}$ antibodies

\begin{tabular}{lcccc}
\hline & $\begin{array}{c}\text { Anti-HCV } \\
\text { positive }\end{array}$ & $\begin{array}{c}\text { Anti-HCV } \\
\text { negative }\end{array}$ & $P$ & OR (95\% CI) \\
\hline $\mathrm{n}(\%)$ & $17(15)$ & $97(85)$ & & \\
Males & $15(88)$ & $82(84)$ & 0.51 & \\
Mean age (years $\pm \mathrm{SD})$ & $38.4 \pm 8.9$ & $41.7 \pm 13.6$ & 0.96 & \\
Mean daily AI $(\mathrm{g} \pm \mathrm{SD})$ & $276 \pm 268$ & $195 \pm 155$ & 0.62 & \\
Mean AI duration (years $\pm \mathrm{SD})$ & $12.3 \pm 11.2$ & $8.7 \pm 10.5$ & 0.21 & \\
Mean ALT (IU/L) & $42 \pm 41$ & $22 \pm 20$ & 0.02 & \\
Elevated ALT [n (\%)] & $11(65)$ & $33(34)$ & 0.02 & \\
AST/ALT ratio & $1.05 \pm 0.4$ & $1.19 \pm 0.6$ & 0.26 & \\
Parenteral risk factors [n $(\%)]$ & $16(94)$ & $10(10)$ & $<0.001$ & $139,2(16-3129)$ \\
Intravenous drug use & $13 / 16(81) *$ & $2 / 10(20)$ & $<0.001$ & $154,4(21-1535)$ \\
Blood transfusion only** & $3 / 16(18)$ & $8 / 10(80)$ & 0.021 & $2,38(0,4-11,7)$ \\
\hline
\end{tabular}

$\mathrm{SD}=$ standard deviation; $\mathrm{Al}=$ alcohol intake;

$\mathrm{ALT}=$ alanine aminotransferase; $\mathrm{AST}=$ aspartate aminotransferase

ALT = alanine aminotransferase; AST = aspartate aminotransferase
$*$ two patients with intravenous drug use in this group also had blood transfusions;

**

Comparison between alcoholic patients with and without elevated aminotransferases

When patients with elevated ALT and/or AST $(n=49)$ were compared to those with normal ALT and AST $(n=65)$, significant differences were found in the rate of patients with positive anti$\mathrm{HCV}$ antibodies ( $24 \%$ vs. $7 \%$ respectively; $P=0.01$ ). Furthermore, a separate analysis of 17 anti-HCV positive patients showed a significantly higher rate of detectable HCV-RNA among the 12 patients with elevated aminotransferases when compared to the 5 patients with normal aminotransferase levels ( $92 \%$ vs. $20 \%$ respectively; $P=0.009$ ). There was no significant difference 
between both groups regarding the following variables: sex, mean age, mean daily alcohol consumption, and mean duration of alcohol use (Table 2).

TABLE 2 - Comparison between alcoholic patients with and without elevated aminotransferases

\begin{tabular}{lccc}
\hline & $\begin{array}{c}\text { Elevated } \\
\text { aminotransferases }\end{array}$ & $\begin{array}{c}\text { Normal } \\
\text { aminotransferases }\end{array}$ & $P$ \\
\hline $\mathrm{n}(\%)$ & $49(43)$ & $65(57)$ & \\
Males & $42(87)$ & $55(85)$ & 0.87 \\
Mean age (years $\pm \mathrm{SD})$ & $43.6 \pm 10.3$ & $39.3 \pm 14.5$ & 0.06 \\
Mean daily AI $(\mathrm{g} \pm \mathrm{SD})$ & $201 \pm 165$ & $210 \pm 184$ & 0.76 \\
Mean AI duration $($ years $\pm \mathrm{SD})$ & $8.8 \pm 10.4$ & $9.6 \pm 10.9$ & 0.35 \\
Anti-HCV positive [n $(\%)]$ & $12(24)$ & $5(7)$ & 0.01 \\
With positive HCV-RNA & $11 / 12(92)$ & $1 / 5(20)$ & 0.009 \\
\hline
\end{tabular}

$\mathrm{SD}=$ standard deviation; $\mathrm{Al}=$ alcohol intake

\section{DISCUSSION}

The prevalence of anti-HCV antibodies among alcoholic patients is higher when compared to the general population and the rate seems to vary according to the presence or absence of co-existing liver disease ${ }^{(28)}$. Indeed, serum markers for $\mathrm{HCV}$ infection have been detected in $33 \%$ to $50 \%$ of alcoholic patients with evidence of liver injury, compared to only $2 \%$ to $10 \%$ in those without any sign of liver disease ${ }^{(4,5,7,10,13,15,21,23,24,25,26,27,30,33,35)}$.

In the present study, anti-HCV antibodies were detected in $17(15 \%)$ of 114 unselected alcoholic patients admitted to our detoxification unit. This result is several-fold higher than the $1.7 \%$ prevalence of positive anti-HCV antibodies reported recently in a sample of almost 40,000 blood donors from the same area ${ }^{(1)}$. However, a very similar prevalence $(16 \%)$ was found in a recent review of published data involving 799 unselected individuals with alcohol abuse ${ }^{(17)}$. Previous studies conducted in Brazil also found anti-HCV antibodies in $12 \%$ to $16 \%$ of unselected alcoholic patients ${ }^{(6,8,14)}$. In contrast, serum markers of $\mathrm{HCV}$ infection were detected in up to $36 \%$ of Brazilian patients with alcoholic cirrhosis ${ }^{(31)}$.

Most alcoholics with anti-HCV antibodies and evidence of liver disease also have HCV-RNA detectable in serum ${ }^{(28)}$. Several independent studies have showed that $56 \%$ to $86 \%$ of anti-HCV positive alcoholic patients were also HCV-RNA positive by $\mathrm{PCR}^{(4}$, $7,10,13,17,24,32)$. We found serum HCV-RNA in $12(71 \%)$ of our 17 alcoholic patients with anti-HCV antibodies. Genotype 1 was observed in more than half of the cases and genotype 3 in the remaining. This profile is similar to that recently described in a study with unselected $\mathrm{HCV}$-infected patients from the same geographical area ${ }^{(19)}$.
Ninety two percent of our anti-HCV positive patients with elevated aminotransferases also had HCV-RNA detectable in serum. In contrast, only $20 \%$ of the ones with normal aminotransferases had detectable HCV-RNA. The high positive predictive value for positive HCV-RNA among those patients with elevated aminotransferases renders PCR testing almost dispensable in this group. In this regard, HCV-RNA testing seems to be most valuable among alcoholics with anti-HCV antibodies and normal aminotransferases, because in this group there is a higher chance for a negative PCR result. The use of recombinant immunoblot assay (RIBA) test could contribute to distinguish individuals with true $\mathrm{HCV}$ infection in the past followed by spontaneous resolution from those with a false-positive enzyme-linked immunosorbent assay (ELISA) test, however, this methodology was not employed in our study.

Regarding the epidemiology of HCV among alcoholic patients, several studies found a strong association between serum markers for $\mathrm{HCV}$ infection and the presence of parenteral risk factors ${ }^{(3,4,7,10,11,13,16,21,23,27,33)}$. Interestingly, other authors showed a remarkably low prevalence of parenteral risk factors among alcoholic patients with anti-HCV antibodies ${ }^{(7,23,30)}$. This controversy may be explained by the high false-positive rate of first generation anti-HCV tests employed in the earlier studies and also by the possibility of underreporting of intravenous drug use behaviour.

Among our 114 alcoholic patients, 15 (13\%) revealed a history of intravenous drug use and $13(87 \%)$ of those were anti-HCV positive. In contrast, among the 99 individuals without a history of intravenous drug use, only four (4\%) were anti-HCV positive, and three $(75 \%)$ of them had a blood transfusion prior to 1992 . These results clearly demonstrate that in our experience, most alcoholic patients with evidence of HCV infection have a clearly identifiable parenteral risk factor, either intravenous drug use or blood transfusion prior to 1992. Indeed, among our 17 anti$\mathrm{HCV}$ positive alcoholics, there was only one case in which we were not able to find an association between the positive $\mathrm{HCV}$ status and the history of a defined parenteral risk factor. Also, our findings suggest that parenteral exposure through the use of intravenous drugs is the main risk factor for $\mathrm{HCV}$ infection among alcoholic patients.

In conclusion, the present study showed a high prevalence $(15 \%)$ of anti-HCV antibodies among unselected alcoholics consecutively admitted to a detoxification unit. Moreover, we found that most patients ( $71 \%$ ) had serum HCV-RNA detectable by PCR, especially those with elevated aminotransferases $(92 \%)$. In our population, there was a strong association between positive anti-HCV antibodies and a history of intravenous drug use $(87 \%)$. We believe these findings can be useful to design future healthcare strategies aimed at improving the management of alcoholic patients admitted for detoxification. 
Galperim B, Cheinquer H, Stein A, Fonseca A, Lunge V, Ikuta N. Prevalência do vírus da hepatite C em alcoolistas: a atuação dos fatores de risco parenterais. Arq Gastroenterol. 2006;43(2):81-4.

RESUMO - Racional - A prevalência da infecção pelo vírus da hepatite C (VHC) é elevada em pacientes alcoolistas, porém os fatores de risco não estão bem estabelecidos. O papel dos fatores de risco parenterais permanece ainda indefinido nessa população. Objetivos - Determinar a prevalência da infecção pelo VHC em alcoolistas internados em uma unidade de desintoxicação, e avaliar a presença de fatores de risco parenteral subjacentes. Pacientes e Métodos - Foram estudados 114 alcoolistas, não selecionados, consecutivamente admitidos em uma unidade de dependência química durante 14 meses. Através de questionário estruturado, obtiveram-se os dados epidemiológicos e história de fatores de risco parenteral para infecção pelo VHC. Foi coletado sangue para determinação de aminotransferases e anticorpos anti-VHC (ELISA-3). As amostras positivas foram confirmadas pela PCR e determinado o genótipo. Resultados - Entre os 114 alcoolistas, 17 (15\%) eram anti-VHC positivos. Doze (71\%) tinham RNA do VHC detectável por PCR no soro. O genótipo 1 foi encontrado em seis casos e o genótipo 3 em cinco (em um paciente foi indeterminado). Quarenta e quatro (43\%) pacientes tinham ALT e/ou AST elevadas. A comparação entre os 17 pacientes positivos e os 97 negativos mostrou diferenças significativas na média do nível da ALT (42 \pm 41 UI/L vs. $22 \pm 20$ UI/L), na taxa de ALT elevada (65\% vs. $34 \%$ ), e na presença de fatores de risco parenteral ( $94 \%$ vs. 10\%). A comparação entre alcoolistas com e sem aminotransferases elevadas mostrou diferença significativa apenas na taxa de anti-VHC positivo (24\% vs. 7\%). Entretanto, entre os 17 pacientes anti-VHC positivos, a taxa de RNA do VHC detectável no soro foi significativamente maior entre os 12 com aminotransferases elevadas do que entre os 5 com aminotransferases normais (92\% vs. 20\%). Conclusão - A prevalência de anti-VHC foi elevada em alcoolistas, sendo a maioria confirmada pela presença do RNA do VHC no soro. O uso de drogas injetáveis foi o principal fator de risco para infecção pelo VHC nesta população.

DESCRITORES - Hepatite C. Alcoolismo. Abuso de substâncias por via endovenosa.

\section{REFERENCES}

1. Almeida PRL, Mattos AA, Ulbrih-Kutczynski J, Cerski CT, Geyer G. Prevalência e impacto histopatológico da infecção pelo vírus $\mathrm{C}$ em doadores de sangue. GED Gastroenterol Endosc Dig. 1998;17:121-8.

2. Altman DG. Practical statistics for medical research. London: Chapman and Hall; 1991.

3. Balasekaran R, Bulterys M, Jamal MM, Quinn PG, Johnston DE, Skipper B, Chaturvedi $\mathrm{S}$, Arora S. A case-control study of risk factors for sporadic hepatitis $\mathrm{C}$ virus infection in the southwestern United States. Am J Gastroenterol. 1999;94:1341-6.

4. Befrits R, Hedman M, Blomquist L, Allander T, Grillner L, Kinnman N, Rubio C, Hultcrantz R. Chronic hepatitis $\mathrm{C}$ in alcoholic patients: prevalence, genotypes, and correlation to liver disease. Scand J Gastroenterol. 1995;30:1113-8.

5. Bode JC, Alscher DM, Wisser H, Bode C. Detection of hepatitis C virus antibodies and hepatitis C virus RNA in patients with alcoholic liver disease. Alcohol. 1995;30:97-103.

6. Both CT, Rossa I, Segura E, Dalla-Costa J, Chaves AL, Mattos AA. Prevalência e implicações do vírus da hepatite C em alcoolistas. Rev AMRIGS. 1996;40:217-20.

7. Caldwell SH, Li X, Rourk RM, Millar A, Sosnowski KM, Sue M, Barritt AS, McCallum RW, Schiff ER. Hepatitis $C$ infection by polymerase chain reaction in alcoholics: false-positive ELISA results and the influence of infection on a clinical prognostic score. Am J Gastroenterol. 1993;88:1016-21.

8. Cavazzola LT, Arruda CA, Reckziegel R, Gr" uber AC, Galperim B, Maia CR, Barros SGS. Frequency of positive antibodies against the hepatitis "C" virus in alcoholics in Brazil - A pilot study [abstract]. Hepatology. 1994;19:511.

9. CDC. Recommendations for prevention and control of hepatitis $\mathrm{C}$ virus (HCV) infection and HCV-related chronic liver diseases. MMWR. 1998;47:1-39.

10. Coelho-Little ME, Jeffers LJ, Bernstein DE, Goodman JJ, Reddy KR, de Medina M, Li X, Hill M, La Rue S, SchiffER. Hepatitis C virus in alcoholic patients with and without clinically apparent liver disease. Alcoholism. Clin Exp Res 1995;19:1173-6.

11. Fingerhood M, Jasinski DR, Sullivan JT. Prevalence of hepatitis C in a chemically dependent population. Arch Intern Med. 1993;153:2025-30.

12. Fletcher RH, Fletcher SW, Wagner EH. Epidemiologia clínica: elementos essenciais. 3a ed. Porto Alegre: Artes Médicas; 1996.

13. Fong T-L, Kanel GC, Conrad A, Valinluck B, Charboneau F, Adkins RH. Clinical significance of concomitant hepatitis $\mathrm{C}$ infection in patients with alcoholic liver disease. Hepatology. 1994;19:554-7.

14. Fonseca JCF, coordenador. Epidemiologia da infecção pelo vírus da hepatite $\mathrm{C}$ no Brasil. Relatório do Grupo de Estudo da Sociedade Brasileira de Hepatologia. GED Gastroenterol Endosc Dig. 1999;18:53-8.

15. Gonzalez-Quintela A, Alende R, Aguilera A, Tome S, Gude F, Perez Becerra E, Torre A, Martinez Vazquez JM, Barrio E. Hepatitis $\mathrm{C}$ virus antibodies in alcoholic patients. Rev Clin Esp. 1995;195:367-72.

16. Goodrick MJ, Anderson NAB, Fraser ID, Rouse A, Pearson V. History of previous drug misuse in HCV-positive blood donors. Lancet. 1992;339:502-3.

17. Heintges T, Wands JR. Hepatitis C virus: epidemiology and transmission. Hepatology. 1997;26:521-6.

18. Hepatitis C. Wkly Epidemiol Rec. 1997;72:65-72

19. Krug LP, Lunge VR, Ikuta N, Fonseca AS, Cheinquer H, Ozaki LS, Barros SG. Hepatitis C virus genotypes in Southern Brazil. Braz J Med Biol Res. 1996;29:1629-32.
20. Laskus T, Radkowski M, Lupa E, Horban A, Cianciara J, Slusarczyk J. Prevalence of markers of hepatitis viruses in out-patient alcoholics. J Hepatol. 1992;15:174-8.

21. McHutchison JG, Leal RJ, Govindarajan S, Redeker AG. Hepatitis C antibodies in patients with alcoholic liver disease commonly have an identifiable risk factor. J Clin Gastroenterol. 1992;15:233-5.

22. Mendenhall CL, Seeff L, Diehl AM, Ghosn SJ, French SW, Gartside PS, Rouster SD, Buskell-Bales Z, Grossman CJ, Roselle GA. Antibodies to hepatitis B virus and hepatitis $\mathrm{C}$ virus in alcoholic hepatitis and cirrhosis: their prevalence and clinical relevance. Hepatology. 1991;14:581-9.

23. Mendenhall CL, Moritz T, Rouster S, Roselle G, Polito A, Quan S, DiNelle RK. Epidemiology of hepatitis C among veterans with alcoholic liver disease. Am J Gastroenterol. 1993;88:1022-6.

24. Nishiguchi S, Kuroki T, Yabusako T, Seki S, Kobayashi K, Monna T, Otani S, Sakurai M, Shikata T, Yamamoto S. Detection of hepatitis C virus antibodies and hepatitis C virus RNA in patients with alcoholic liver disease. Hepatology. 1991;14:985-9.

25. Oshita M, Hayashi N, Kasahara A, Hagiwara H, Mita E, Naito M, Katayama K, Fusamoto $\mathrm{H}$, Kamada T. Increased serum hepatitis $\mathrm{C}$ virus RNA levels among alcoholic patients with chronic hepatitis C. Hepatology. 1994;20:1115-20.

26. Parés A, Barrera JM, Caballería J, Ercilla G, Bruguera M, Caballeria L, Castillo R, Rodes J. Hepatitis C virus antibodies in chronic alcoholic patients: association with severity of liver injury. Hepatology. 1990;12:1295-9.

27. Rosman AS, Waraich A, Galvin K, Casiano J, Paronetto F, Lieber CS. Alcoholism is associated with hepatitis $\mathrm{C}$ but not hepatitis $\mathrm{B}$ in an urban population. Am J Gastroenterol. 1996;91:498-505.

28. Schiff ER. Hepatitis C and alcohol. Hepatology. 1997;26:39s-42s.

29. Simmonds P, McOmish F, Yap PL, Chan SW, Lin CK, Dusheiko G, Saeed AA, Holmes EC. Sequence variability in the 5 ' non-coding region of hepatitis $C$ virus: identification of a new virus type and restrictions on sequence diversity. J Gen Virol. 1993;74:661-8.

30. Srugo I, Shinar E, Bar-Shany S, Amos L. Hepatitis B and C markers among alcoholics in Israel: high incidence of HCV infection. Eur J Epidemiol. 1998;14:333-7.

31. Strauss E, Sá MFG, Gayotto LCC, Takada N, Takada A. Relationship of serum gammaglobulin levels with hepatitis $\mathrm{C}$ markers in alcoholic cirrhosis and hepatosplenic schistosomiasis [abstract]. Hepatology. 1992; 16:594.

32. Takase S, Takada N, Enomoto N, Yasuhara M, Takada A. Different types of chronic hepatitis in alcoholic patients: does chronic hepatitis induced by alcohol exist? Hepatology. 1991;13:876-81.

33. Verbaan H, Andersson K, Eriksson S. Intravenous drug abuse - the major route of hepatitis $\mathrm{C}$ virus transmission among alcohol-dependent individuals? Scand $\mathrm{J}$ Gastroenterol. 1993;88:714-8.

34. World Health Organization. The ICD-10 Classification of Mental and Behavioral Disorders Clinical. Descriptions and Diagnosis Guidelines. Geneva: WHO; 1992.

35. Zignego AL, Foschi M, Laffi G, Monti M, Careccia G, Romanelli RG, De Majo E, Mazzanti R, Buzzelli G, La Villa G. "Inapparent" hepatitis B virus infection and hepatitis $\mathrm{C}$ virus replication in alcoholic subjects with and without liver disease. Hepatology. 1994;19:577-82.

Recebido em 4/7/2005. Aprovado em 27/10/2005 